\title{
Development of an Interactive Learning Media to Improve Competencies
}

\author{
Eko Swi Damarwan, Moh. Khairudin \\ Dept. Electrical Engineering, Post Graduated School Yogyakarta State University \\ Yogyakarta, Indonesia \\ ekoswidamarwan@gmail.com; moh_khairudin@uny.ac.id
}

\begin{abstract}
This study aims to develop an interactive learning media on the subject of Electrical Engineering (Teknik Listrik); to determine the feasibility of the media developed, and to know the students' responses. Learning media is an important component in the learning process. Technology and computerbased media is one of the media needed. It aims to attract students to learn the material, especially material that need more efforts to understand. Media development is created due to lack of students' interest, motivation, and in the subject. The media was developed using ADDIE model, namely analysis, design, development, implementation, and evaluation. Questionnaires were used for data collection. The media was tested in first grade students of vocational secondary school. The results show interactive learning media is considered feasible for use.
\end{abstract}

Keywords-electrical engineering (teknik listrik), Interactive, Media

\section{INTRODUCTION}

Learning is a process of gaining experience and knowledge to change behavior. Learning process is the process of transferring knowledge from teacher to student [1]. Learning and teaching process is an activity to implement the curriculum of educational institution in order to influence the students in achieving educational goals that have been set [2].

Optimal delivery of material needs suitable media. The media is a means of channeling messages from the teacher to the students so as to stimulate the mind, and the interests of students performance participating in learning activities [3]. However, a lot of obstacles encountered during the learning process in classroom may result in lowering students' interest and making them feel bored.

Students are less interested in following the study because the teacher's delivery of learning materials is too monotonous. Teacher centered learning model is more focused on the teacher and reduce motivation and activeness of students in the classroom [4]. In addition, the media used tend to the whiteboard and simple power point.

Based on observations, if viewed in terms of infrastructure in vocational school, actually there are computers and the Internet, but the connection is substandard and not used optimally. The computer needs to be optimized. Utilization of the computer as a media in the learning process has been widely applied and developed in the form of computer-based learning media. This learning media can be used either online by using the internet or offline.

At the beginning of the history lesson, the media is only a tool that is used to explain the lesson teacher. An effort to utilize the media as a tool, Edgar Dale classifies a media from the most concrete to the most abstract. Fig.1 presents a classification of media as Cone of experience [5].

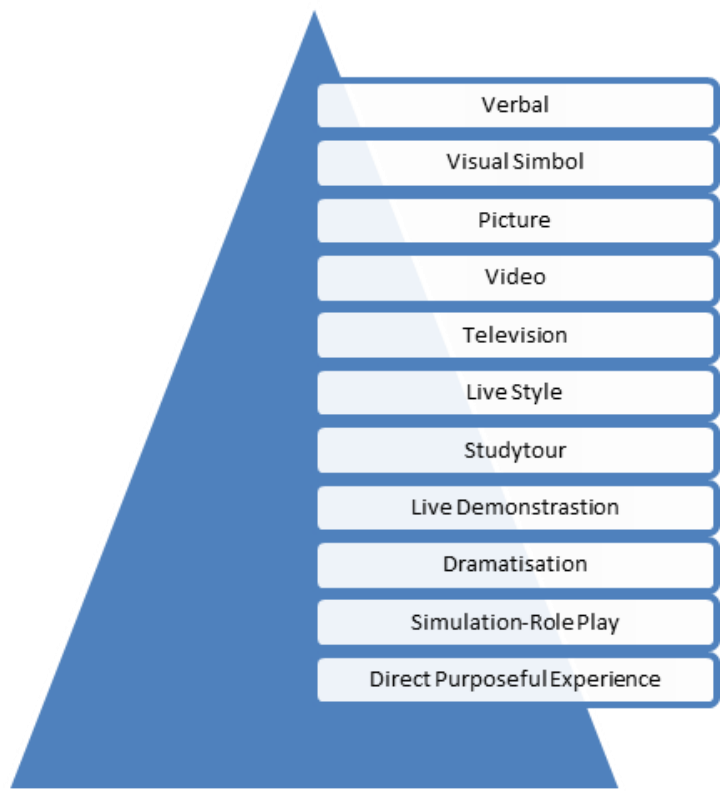

Fig. 1. Classification of media according to Dale

Based on the form of presentation and the way it is presented, instructional media are grouped into seven groups of media renderer namely (a) the first group unity consisting of graphics, print materials and still images, (b) the second group is silent projection media, (c) the third group is audio media, (d) the fourth group are audio-visual media silence, (e) the fifth group are media live image or movie, (f) the sixth group is television media, and $(\mathrm{g})$ the seventh group is multimedia [6].

Interactive multimedia is a concept in the field of computer technology where components such as images, text, animation, and video are combined into one to be presented interactively [7]. Agree with it, Mayer [8] says multimedia as the presentation of material using both words and pictures. Media learning using a computer-based media (Adobe Flash) is 
combined with Kahoot evaluation. The main advantage of this learning media is its ability to take advantage of all the capabilities of the computer. Interactive media is suitable for use in vocational students [9]. Use of interactive media may increase understanding and students' motivation [10].

Electrical Engineering (Teknik Listrik) material is basically concepts and principles of electronics and electricity. Electrical Engineering material is delivered to first grade students of Electronics Industry expertise package in Muhammadiyah Prambanan vocational secondary school. This subject is taught over two semesters consisting of theory as well as practice. The subject competencies include measurement electronics, laws and concepts of electricity.

The advantages of interactive learning media is expected to provide an important role in the achievement of learning objectives, especially in subjects that have a charge of material has been difficult subjects such as Electrical Engineering. Interactive media is more effective than conventional media [11]. This study consists of using Design, Development or Production, Implementation and Evaluation (ADDIE) method, the discussion of the feasibility of the media, and the conclusions of development interactive learning media.

\section{METHODS}

The development method used in this study is an ADDIE model. ADDIE is an acronym for Analysis, Design, Development or Production, Implementation and Evaluation [12]. This model can be used for wide variety of products such as model of development, learning strategy, learning methods, media and teaching materials. ADDIE steps are shown in Fig 2.

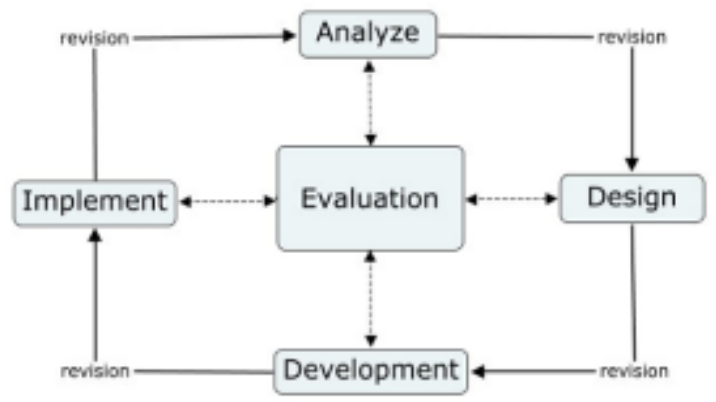

Fig. 2. Steps of ADDIE

First step in ADDIE is Analysis. The analysis phase includes two important things, i.e., needs assessment and front end analysis.

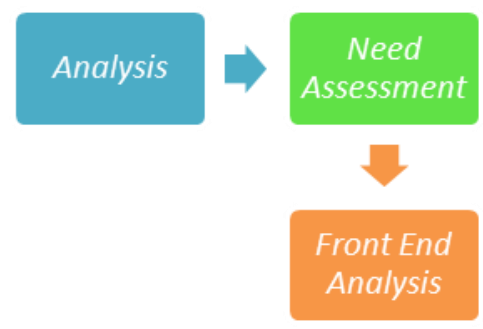

Fig. 3. Steps of Analysis
Fig. 3 describes steps of Analysis. In the need assessment, there are several things that need to be considered in the development process, namely, analysis of current conditions, ideal conditions, the gap, and a list of alternative employment, the priority of work to solve the problems. The next step is front end analysis. Front end analysis phase includes: needs analysis, analysis of student characteristics, objective analysis, material analysis, and analysis of media.

The next step is media design. This phase begins with a drafting of interactive multimedia learning. This draft will be useful to make a flowchart. Furthermore, through a flowchart a storyboard will be created as a basis for the development of instructional media.

The development phase is to make the initial product. Subsequently, the product was validated by expert team, namely, subject matter experts and media experts. The products have been validated subsequently revised in accordance to advice of an expert media. The next step is finishing a ready product to be tested with students.

The phase of Implementation is that the products have been revised on the advice of a team of experts (subject matter experts and media specialists) and declared eligible for tested. The trial is conducted in small groups of 30 students in first grade students of Muhammadiyah Prambanan Vocational Secondary School. Media is validated before tested to students. Validity test used a material and media validity. Material validity test was conducted by giving several questions to expert opinion (expert judgment). Furthermore a media validity test was conducted by media expert. Validation results are shown in Table I.

TABLE I. RESULTS OF EXPERT JUDGMENT VALIDATION

\begin{tabular}{|l|l|l|l|l|}
\hline \multirow{2}{*}{ Aspect } & \multicolumn{3}{c|}{ Value } & \multirow{2}{*}{ Category } \\
\cline { 2 - 4 } & Min & \multicolumn{1}{|c|}{ Ave } & Max & \\
\hline Media Expert & 74 & 79.5 & 85 & Very good \\
\hline Material Expert & 72 & 74 & 76 & Good \\
\hline
\end{tabular}

Table I describes the results of expert validation. Media experts presented that media including the very good category, with an average value of 79.5. While the material experts stated that the media have a good category to be used, with an average value of 74 .

Evaluation stage is the final stage. Evaluation happens at each of four stages of a formative evaluation. Media specialists and subject matter experts evaluated the media using questionnaires media validation and questionnaires material validation, whereas students evaluated the media using student questionnaire responses to determine the response of students to instructional media that have been made.

\section{RESULTS AND DISCUSSION}

Based on observations in vocational secondary school, following characteristics were found: (1) There are are 30 students in the Electronic Industries Programs (ELINS). (2) The students are competence to operate a computer. (3) These students condition is in low economics class. (4) The medium 
language used by teachers and students are Indonesian, but in non-formal speaking often use the Java language.

Based on analysis of technology, several computers were found in laboratory and library, and the internet access is also available in the school areas. In the ELINS classrooms, there are LCD projectors used for learning process. Most students and all teachers have laptops. Only a few students are using smartphones but most teachers have a smartphone.

Analysis of condition can be known, classrooms have lighting standard. Theory classroom and workshop location were separated. In theory classroom and computer laboratory obtained two Air Conditioners (AC), otherwise in workshop only used a fan. Classrooms position far enough from the highway, so the noise level is low.

The objective analysis is used to find the data about the student competence to understand and explain the Electrical Engineering subject. The contents of this basic competency include: (1) introduction of measuring instruments, (2) Identification of measuring instruments, (3) principle of measuring instruments, (4) reading a color code of resistor values, (5) circuits of DC series, and (6) parallel series circuits. Media development plan is presented in Fig.4.

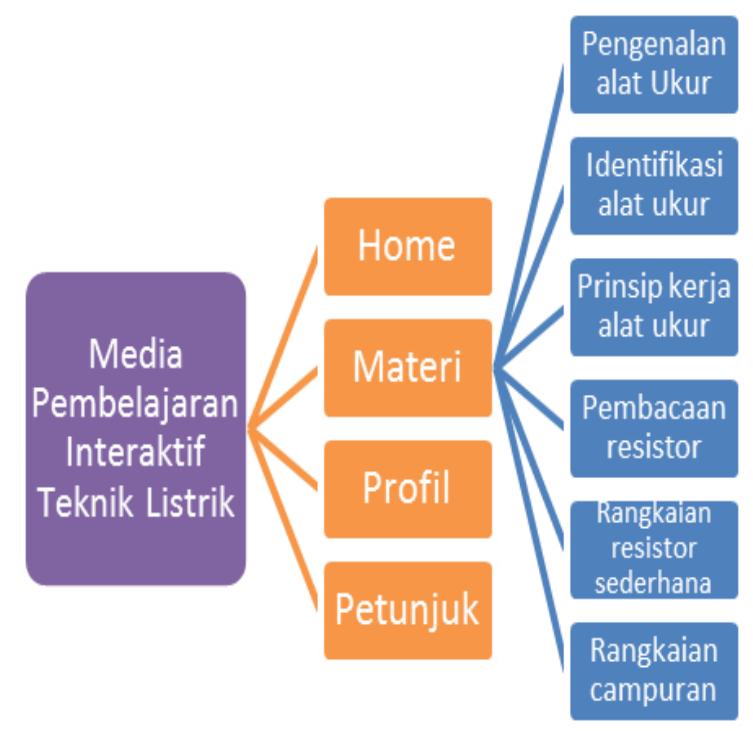

Fig. 4. Media Development Plan

In analysis of media process, it is found that a flash interactive learning media need to be developed and packaged attractively. This media provides electrical circuits material that is supported by resistor measurement video and electrical engineering animation.

Furthermore, the media was evaluated in accordance with the advice of experts. Fig. 5 presents the home menu of interactive media after being evaluated by experts.

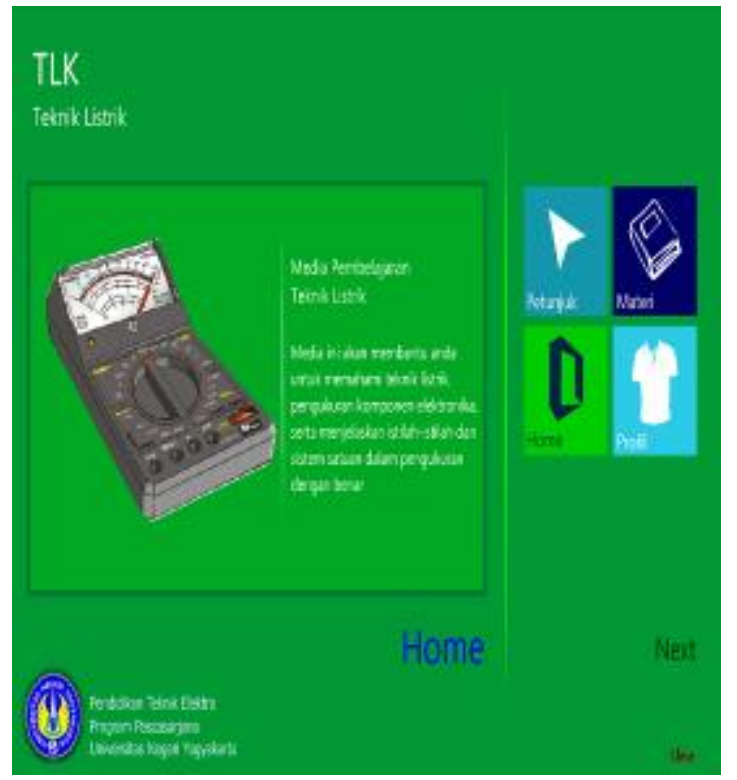

Fig. 5. Home Menu of Media

Students use the softcopy of this interactive media and it can be studied alone in their homes. This interactive media consist of images, animations, and videos that serve to help students learn. Fig. 6 illustrates an animation contained in interactive media.

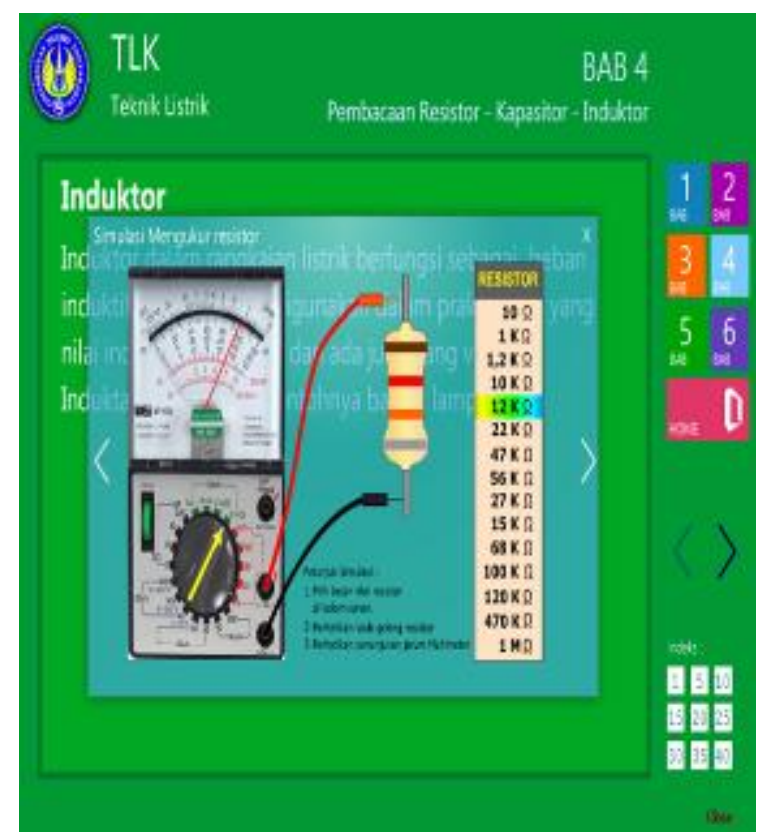

Fig. 6. Interactive Learning Media

To increase the interest of students, this media added the evaluation of material using software application of Kahoot . Evaluation using Kahoot can be carried out either face to face or using the Internet. Kahoot evaluation start menu is shown in Fig.7. 


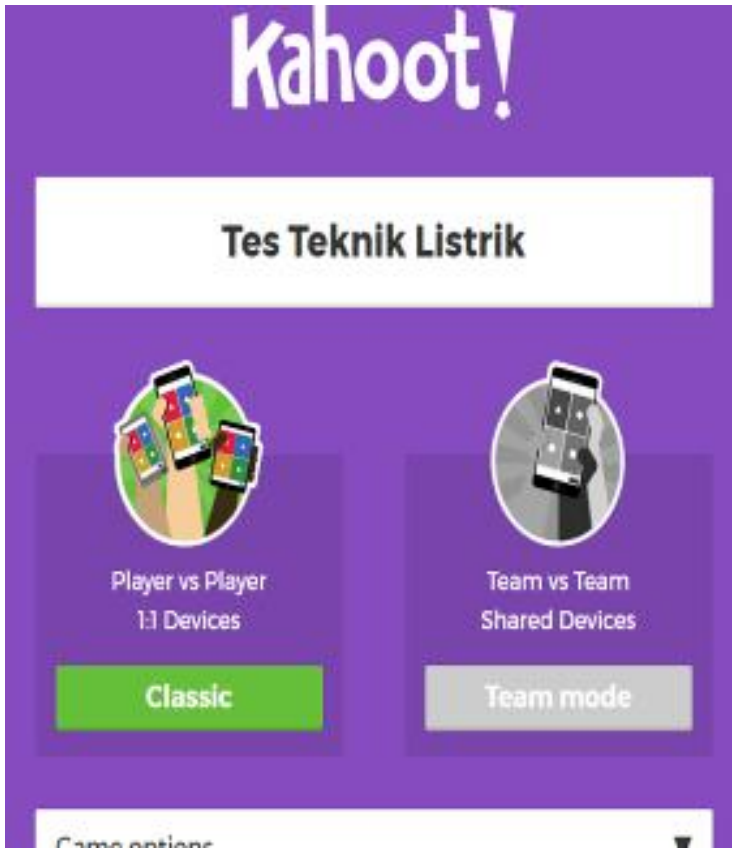

Fig. 7. Start Menu of Kahoot

Test the feasibility of media through student responses was viewed from four aspects, namely: the material, creative, interactive, and ease of use. Material aspects include material contents, material of detail, and suitability objectives material given to students. The creative aspects are in terms of the interest of students to the media, media evaluation forms, and the student's ability to solve the problems. Interactive aspect consists of media navigation display, images, language use, animation, and video support material. The ease of use aspect is an aspect of assessing the ease of use of interactive media for vocational students. Graph feasibility media is presented in Fig.8.

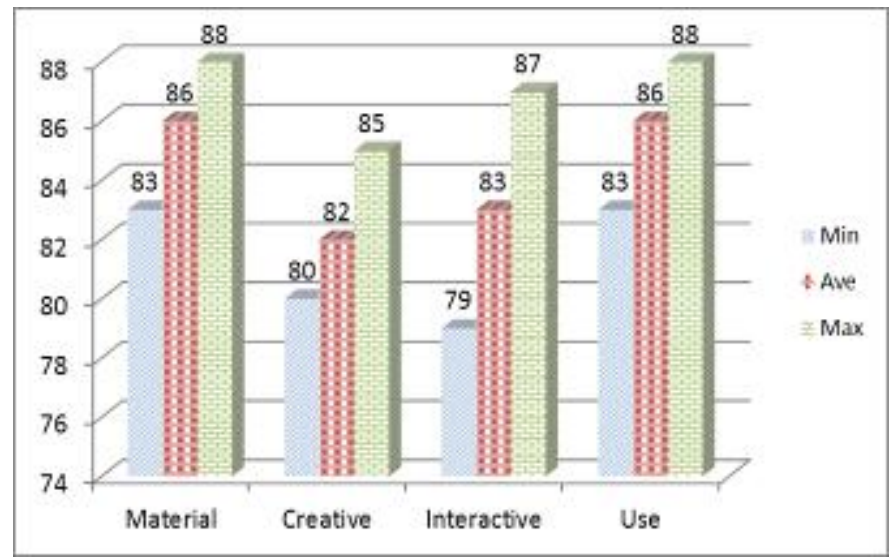

Fig. 8. Graph Feasibility Media
Fig. 8 can be explained that the feasibility of the media in terms of material aspects and usage has highest average feasibility value of 86 , while the creative aspect has a lowest eligibility value of 82 . The views of the minimal value is interactive aspect has the lowest minimum score of 79 . However, the interactive media of electrical engineering is already considered very feasible to use because it has an average of more than 75 .

\section{CONCLUSION}

Motivation and understanding of students in the following Electrical Engineering lesson are still low. An interesting learning media is needed to overcome it. Interactive learning media of Electrical Engineering can be as one of the solutions. It has advantages that it can combine multiple media such as text, images, audio, video, and animation. The entire convergent media support each other and merge into one medium to deliver information or messages that are very large. The existence of interactive media is very suitable for use in electrical engineering. This media can increase students' motivation on the subjects of Electrical Engineering.

\section{REFERENCES}

[1] H. Oemar, Proses Belajar Mengajar. Jakarta: PT Bumi Aksara, 2010.

[2] Nana Sudjana \& Rivai Ahmad., Media Pengajaran. Bandung: Sinar Baru Algesindo, 2013.

[3] A. Sadiman, Media Pendidikan. Jakarta: Raja Grafindo, 2010

[4] E. \& M. Sutarno, "Pengembangan Model Pembelajaran Berbasis Multimedia Kemandirian Belajar Siswa SMP di Kota Bandung," Jurnal Pendidikan Teknolologi dan Kejuruan., vol. 21, no. 3, pp. 203218, 2013.

[5] D. Indriana, Ragam Alat Bantu Media Pengajaran. Yogyakarta: Divapress, 2011.

[6] R. S. \& C. Riyana, Media Pembelajaran. Kurtekpend FIP UPI, 2008

[7] Nopriyanti, "Pengembangan Multimedia Pembelajaran Interaktif Kompetensi Dasar Pemasangan Sistem Penerangan dan Wiring Kelistrikan Di SMK," Jurnal. Pendidikan Vokasi, vol. 5, no. 2, pp. 222-235, 2015.

[8] R. E. Mayer, Multimedia Learning. New York: Cambridge University Press, 2001

[9] Sulistyono, "Pengembangan Multimedia Interaktif Berbasis Flash pada Siswa SMK TKJ.," E prints uny, 2013.

[10] A. M. Yusuf, "Pengembangan Media Pembelajaran Berbasis Adobe Flash untuk Mata Kuliah Fiska Modern Materi Radiasi Benda Hitam," Jurnal Sains dan Pendidikan Fiika., vol. 11, no. 1, pp. 57-71, 2015.

[11] Suyitno, "Pengembangan Multimedia Interaktif Pengukuran Teknik untuk Meningkatkan Hasil Belajar Siswa SMK," Jurnal Pendidikan Teknologi dan Kejuruan., vol. 23, no. 1, pp. 101-109, 2016.

[12] W. William Lee \& L. Diana Owen, Multimedia- Based Instructional Design: Computer-based Training Web based Training Distance Broadcast Training Performance based Solution. New York: Pfeifier, 2004. 